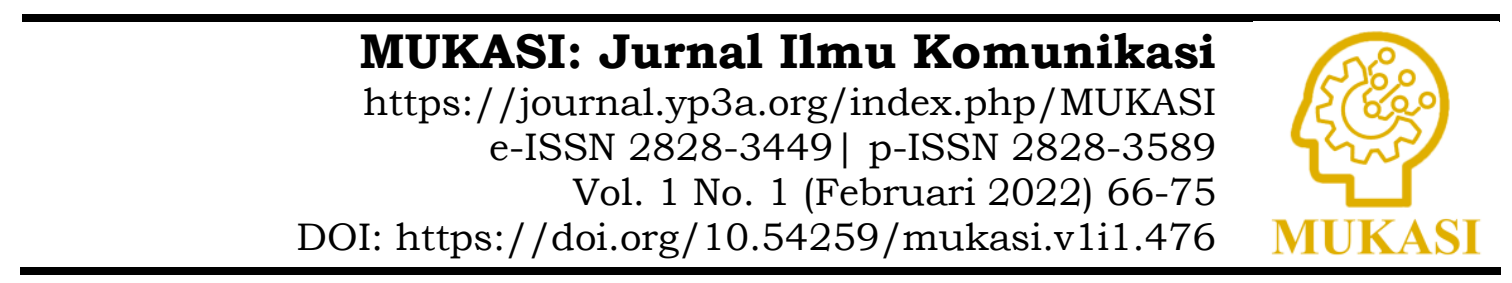

\title{
Proses Komunikasi Tim Program Kelurahan Bersinar Dalam Pencegahan Narkoba Di Kelurahan Tanah Seribu Binjai
}

\author{
Ratni Hardiana ${ }^{1}$, Mazdalifah ${ }^{2}$, Sakhyan Asmara ${ }^{3}$ \\ 1,2, ${ }^{1} \mathrm{lmu}$ Komunikasi, FISIP, Universitas Sumatera Utara, Indonesia \\ 19Able1985@gmail.com, ${ }^{2}$ mazdalifah_jalil@yahoo.com, ${ }^{3}$ sakhyanmara@yahoo.com
}

\begin{abstract}
Kelurahan Bersinar (Narcotics-Free Village) program, initiated by the National Narcotics Agency of the Republic of Indonesia, involves various agencies. The objective of the research is to analyze the communication process in the program. The research employs interpretive paradigm with qualitative approach. The data are gathered by conducing in-depth interview, observation, documentation study, and library research. The gathered data are analyzed by using interactive method of Miles and Huberman. The research is done at the Kelurahan Tanah Seribu, Binjai, North Sumatera which is the first narcotics-free village in Binjai. The result of the research shows that the process of communication done by the team is through face to face communication, and through outdoor and indoor communication. The communication barriers found are late distribution of activity tehnical manual books, repeated materials, and people's negative stigma to government employees taking care of the problems related to narcotics abuse.
\end{abstract}

Keywords: Communication Process, Narcotics Prevention, Kelurahan Bersinar (Narcotics-free village) Program.

\begin{abstract}
Abstrak
Program Kelurahan Kelurahan Bersinar yang disingkat dengan Kelurahan Bersinar adalah satu program yang digerakkan oleh Badan Narkotika Nasional Republik Indonesia yang melibatkan berbagai instansi. Tujuan penelitian ini adalah menganalisis proses komunikasi dan hambatan-hambatan komunikasi yang dialami. Penelitian menggunakan paradigma interpretif dengan pendekatan kualitatif, dimana data dikumpulkan melalui wawancara mendalam, observasi, studi dokumentasi dan studi pustaka. Teknik analisa data menggunakan model interaktif dari Miles dan Huberman. Penelitian dilakukan di Kelurahan Tanah Seribu Kota Binjai Sumatera Utara yang merupakan kelurahan bersih anti narkoba pertama yang dicanangkan. Hasil penelitian menunjukkan bahwa proses komunikasi oleh Tim Kelurahan Bersinar dilakukan melalui komunikasi tatap muka, komunikasi melalui media luar dan dalam ruang. Hambatan komunikasi yang ditemukan meliputi buku petunjuk teknis kegiatan yang terlambat didistribusikan, materi yang berulang, dan stigma-stigma negatif masyarakat pada aparat pemerintah yang menangani permasalahan penyalahgunaan narkoba.
\end{abstract}

Kata kunci: Proses Komunikasi, Pencegahan Narkoba, Program Kelurahan Bersinar. 


\section{PENDAHULUAN}

Komunikasi berperan penting dalam kehidupan manusia, karena termasuk ke dalam aktivitas dasar kehidupan. Komunikasi memungkinkan untuk dapat menyampaikan ide dan gagasan yang ada dalam pikiran dalam rangka mempengaruhi orang lain untuk berpikir atau berperilaku seperti yang kita inginkan, hal ini diungkapkan oleh ahli komunikasi Everett Rogers (Cangara, 2014:22).

Komunikasi pembangunan memegang peran penting dalam melaksanakan perencanaan pembangunan suatu negara untuk mencapai tujuan yang telah ditetapkan. Tujuan dari adanya komunikasi dalam pembangunan adalah untuk mengadakan aktivitas pertukaran pesan secara timbal balik diantara semua pihak yang terlibat dalam usaha pembangunan, termasuk di dalamnya masyarakat dan pemerintah.

Salah satu instansi pemerintah yang menggunakan komunikasi pembangunan dalam tugas dan tanggung jawabnya adalah Badan Narkotika Nasional yang fokus kepada pencegahan penyalahgunaan pemberantasan dan peredaran gelap narkotika, psikotropika dan obat-obatan berbahaya (Narkoba) atau yang disingkat dengan P4GN.

Permasalahan narkoba terjadi hampir diseluruh negara yang ada di dunia.

Permasalahan dalam hal penyalahgunaan narkoba perlu mendapat perhatian dan penanganan serius dari berbagai pihak. Berdasarkan data yang dirilis UNODC tahun 2019, terdapat sekitar 271 juta orang, atau sekitar 5,5\% dari populasi global berusia 1564 tahun yang telah atau pernah mengkonsumsi narkoba. Makalah oleh Supratman (2018) menyatakan bahwa ada fenomena lost generation yang akan mengintai Indonesia di masa mendatang jika permasalahan narkoba tidak ditangani secara masif mulai dari sekarang.

Amanat Undang-Undang Dasar Negara Republik Indonesia Tahun 1945 menyebutkan bahwa kualitas sumber daya manusia Indonesia sebagai salah satu modul pembangunan nasional perlu diperlihara dan ditingkatkan secara terus-menerus termasuk derajat kesehatannya. Undang-Undang Republik Indonesia Nomor 35 Tahun 2009 yang mengatur tentang narkotika adalah dasar utama dalam penanganan penyalahgunaan narkoba di Indonesia yang mana dalam pelaksanaan di lapangan memerlukan perencanaan yang baik dan mempertimbangkan banyak strategi untuk mencapai keberhasilan.

Data penelitian tahunan dari BNN 2019 menyebutkan bahwa Sumatera Utara menjadi provinsi dengan peredaran narkoba terbanyak di Indonesia. Angka prevalensi Sumut sebesar 6,5\% dari total keseluruhan penduduk (Puslidatin BNN, 2019). Survey Indeks ketahanan keluarga (IKK) anti narkoba pada tahun 2019 juga menyebutkan bahwa Sumatera Utara mendapat klasifikasi rendah dalam hal ketahanan keluarga terhadap narkoba. Kedua hal ini menjadi indikator bahwa permasalahan penyalahgunaan narkoba di Provinsi Sumatera Utara termasuk mengkhawatirkan.

Tabel 1. Angka Prevalensi Narkoba di Indonesia

\begin{tabular}{cc}
\hline Tahun & $\begin{array}{c}\text { Angka Prevalensi } \\
\text { (dalam persen) }\end{array}$ \\
\hline 2008 & 1,99 \\
2011 & 2,23 \\
2014 & 2,18 \\
2019 & 1,80
\end{tabular}

(Sumber : Pidato Wakil Presiden Peringatan Hari Anti Narkotika Nasional, 2021) 
Salah satu program Badan Narkotika Nasional Republik Indonesia yang menerapkan komunikasi pembangunan adalah Program Kelurahan Bersih Narkoba atau yang dikenal dengan Kelurahan Bersinar. Program Kelurahan/Desa Bersinar adalah program pemberdayaan masyarakat yang mulai diluncurkan pada tahun 2019 dengan dasar hukum Instruksi Presiden Nomor 6 Tahun 2018 tentang Rencana Aksi Nasional Pencegahan dan Pemberantasan Penyalahgunaan dan Peredaran Gelap Narkoba (P4GN) dan Surat Edaran Menteri Dalam Negeri Nomor 354/9041/SJ tanggal 26 Oktober 2018 kepada seluruh gubernur di Indonesia hal pencegahan penyalahgunaan narkoba di desa/kelurahan. Program ini terus digalakkan oleh Badan Narkotika Nasional sampai saat ini, dengan harapan dapat menekan peredaran narkoba dimulai dari satuan pemerintahan terkecil.

Kota Binjai, adalah kota penyangga yang berjarak hanya $8 \mathrm{Km}$ dari perbatasan Kota Medan. Kota dihuni oleh 270 ribu jiwa penduduk dan menempati areal seluas 90,45KM2. Survey Indeks Kota Tanggap Narkoba (IKOTAN) yang diadakan oleh BNN dan Universitas Padjajaran tahun 2018 menunjukkan bahwa Kota Binjai menempati posisi ke 78 dari total 173 kota dengan predikat kurang tanggap. Sebagai kota yang berbatasan dengan Medan, yang merupakan salah satu kota besar di Indonesia, Kota Binjai dapat dianggap sebagai kota transit perdagangan narkoba karena posisi geografisnya yang berada di perbatasan dua provinsi.

Data yang di dapat dari seksi rehabilitasi BNN Kota Binjai menunjukkan penyalahgunaan narkoba di Kelurahan Tanah Seribu dan wilayah sekitarnya termasuk dalam kategori sedang. Kenaikan jumlah pasien lapor rawat jalan di Klinik Pratama Kota Binjai terjadi pada tahun 2019, yang mana hal ini merupakan pertanda baik bahwa telah tercipta kesadaran masyarakat untuk melaporkan tindakan penyalahgunaan kepada petugas yang berwenang.

Walaupun memiliki indikator daerah yang masuk dalam daerah rawan peredaran narkoba, Kelurahan Tanah Seribu pernah menorehkan beberapa prestasi. Kelurahan Tanah Seribu pernah meraih penghargaan sebagai Kelurahan terbaik se-Kota Binjai sehingga diusulkan untuk maju pada nominasi kelurahan terbaik se-provinsi Sumatera Utara pada tahun 2017. Indikator kelurahan terbaik ditetapkan berdasarkan upaya pemberdayaan masyarakat yang baik dalam hal menjaga kebersihan, ketenteraman dan keamanan lingkungan. Kelurahan ini juga menang dalam perlombaan penghapusan kekerasan dalam rumah tangga (KDRT), menerima penghargaan IPAL komunal dari Islamic Development Bank, dan pejabat kelurahan menyatakan berhasil dalam pemberantasan narkoba (https://sumut.antaranews.com/berita/166953/kelurahan-tanahseribu-masuknominasi-terbaik-sumut).

Program Kelurahan Bersinar di Tanah Seribu ini perlu diteliti karena program ini adalah program pertama Kelurahan Bersinar yang dicanangkan di Kota Binjai, sekaligus dapat menjadi evaluasi bagi Kelurahan Bersinar lain yang akan dicanangkan di tahun-tahun berikutnya. Berdasarkan hal-hal yang telah diuraikan tersebut, peneliti tertarik untuk meneliti bagaimana proses komunikasi Tim Program Kelurahan Bersinar dalam pencegahan narkoba di Kelurahan Tanah Seribu Binjai dan hambatan apa saja yang dialami.

\section{TINJAUAN PUSTAKA}

Proses Komunikasi

Proses komunikasi pada prinsipnya meliputi pengiriman dan penerimaan pesan-pesan diantara dua orang atau lebih dengan suatu tujuan tertentu. Harold Lasswell menyatakan bahwa cara yang baik untuk menjelaskan komunikasi adalah dengan menjawab pertanyaan siapa yang menyampaikan, apa yang disampaikan, melalui saluran apa, 
kepada siapa, dan apa pengaruhnya (who? Says what? In which channel? to whom? with what effect?). Everett M. Rogers dan D. Lawrence Kincaid menyatakan bahwa komunikasi adalah suatu proses dimana dua orang atau lebih membentuk atau melakukan pertukaran informasi dengan satu sama lainnya, yang pada gilirannya akan tiba pada saling pengertian yang mendalam (Cangara, 2014:21)

Paradigma Laswell menunjukan bahwa komunikasi meliputi lima unsur utama (Fajar, 2009:30) yaitu komunikator (communicator), pesan (message), media (channel, media), komunikan (communicant, communicate, receiver, recipient, audience), dan efek (effect, impact, influence).

Proses komunikasi pada umumnya akan melewati dua tahap (Effendy, 2020:11), yaitu: (a) Proses komunikasi secara primer, yaitu proses penyampaian pikiran atau perasaan seseorang kepada orang lain dengan menggunakan lambang (symbol) sebagai media. Lambang sebagai media primer dalam proses komunikasi adalah bahasa, isyarat, gambar, warna dan lain sebagainya yang secara langsung mampu menerjemahkan pikiran atau perasaan komunikator kepada komunikan; (b). Proses komunikasi secara sekunder, yaitu proses komunikasi oleh seorang kepada orang lain dengan menggunakan alat atau sarana sebagai media kedua setelah memakai lambang sebagai media pertama. Komunikator menggunakan media kedua dalam melancarkan komunikasinya karena komunikan sasarannya berada di tempat yang relatif jauh atau jumlahnya banyak. bisa berupa surat, perangkat elektronik, media massa, dan lainnya. Pemilihan media yang tepat dalam sebuah proses komunikasi akan sangat menentukan apakah pesan tersampaikan dengan baik atau tidak (Sutisna dalam Novita, 2020:297).

Saat ini penggunaan media komunikasi baik dalam dan luar ruang sudah menjadi bagian dari kehidupan masyarakat. Media ini telah banyak digunakan oleh orang-orang terutama dalam mempromosikan sesuatu. Media luar ruang biasanya diletakkan di ruang terbuka atau di tempat-tempat yang di nilai strategis agar bisa dilihat oleh khalayak. Media dalam ruang adalah jenis media yang mendukung kampanye promosi sebuah mereka atau produk hanya jangkauan target audiens mencakup satu wilayah saja, tidak seluas media dalam ruang. Penggunaan media luar ruang maupun dalam ruang mempunyai tujuan untuk menyampaikan sebuah informasi atau pesan. Bentuk dari media luar ruang seperti baliho, spanduk, reklame, electronic board, umbul-umbul, dan balon iklan cukup memberi pengaruh kepada orang yang sedang berada di luar rumah untuk melihat media tersebut dan berbeda dengan televisi, majalah, dan radio yang diterima di rumah.

Komunikasi Pembangunan

Pembahasan penting dan utama dalam komunikasi pembangunan adalah bagaimana usaha penyebaran pesan-pesan (ide, gagasan dan inovasi) kepada sejumlah besar orang agar dapat menimbulkan efek tertentu yang bermanfaat. Komunikasi pembangunan adalah usaha yang terorganisir untuk menggunakan proses komunikasi dan media dalam meningkatkan taraf sosial dan ekonomi, yang secara umum berlangsung dalam negara sedang berkembang (Peterson dalam Nasution dan Rasyid, 2019:1). Komunikasi pembangunan berorientasi pada tujuan, yaitu kualitas hidup yang lebih tinggi pada suatu masyarakat melalui adanya perubahan sosial dan politik (Cangara, 2020:315).

Agar komunikasi pembangunan lebih berhasil mencapai sasarannya serta dapat menghindarkan kemungkinan-kemungkinan efek yang tidak diinginkan, tentunya harus mempertimbangkan hal-hal yang disorot tadi. Kesenjangan efek yang ditimbulkan oleh kekeliruan cara-cara komunikasi selama ini, menurut Rogers dan Adhikarya (Harun \& Ardianto, 2011: 163) dapat diperkecil bila strategi komunikasi pembangunan dirumuskan sedemikian rupa mencakup prinsip-prinsip tertentu. 
Hambatan Komunikasi

Meskipun kita sudah berkomunikasi dengan sebaik-baiknya namun berkomunikasi dapat menjadi gagal karena berbagai alasan. Usaha untuk berkomunikasi dengan baik bisa saja diganggu oleh hambatan, dimana hambatan komunikasi tersebut dapat mengganggu sebagian proses komunikasi, atau bahkan keseluruhan komunikasi yang terjadi.

Menurut Cruden dan Sherman, hambatan dalam berkomunikasi dapat terjadi karena (dalam Silviani, 2020 :67): (1) Hambatan yang bersifat teknis, berupa kurangnya sarana dan prasarana yang diperlukan dalam proses komunikasi, penguasaan teknik dan metode berkomunikasi yang tidak sesuai, kondisi fisik yang tidak memungkinkan terjadinya proses komunikasi; (2) Hambatan Semantik meliputi hambatan yang berkaitan kesalahan dalam penafsiran, salah dalam pemberian pengertian bahasa, salah dalam menyampaikan pesan dalam proses komunikasi; (3) Hambatan Perilaku meliputi pandangan yang bersifat apriori, prasangka yang didasarkan pada emosi, suasana otoriter, ketidakmauan untuk berubah, dan sifat yang egosentris.

\section{Pencegahan Penyalahgunaan Narkoba}

Pencegahan dipandang sebagai upaya yang lebih murah dan hemat ketimbang upaya lain seperti pemberantasan dan rehabilitasi. Pencegahan dan Pemberantasan Penyalahgunaan dan Peredaran Gelap Narkoba (P4GN) adalah upaya sistematis berdasarkan data penyalahgunaan narkoba yang tepat dan akurat, perencanaan yang efektif dan efisien dalam rangka mencegah, melindungi dan menyelamatkan warga negara dari ancaman bahaya penyalahgunaan narkoba.

Berdasarkan Peraturan Badan Narkotika Nasional Nomor 3 Tahun 2019 Tentang Organisasi dan Tata kerja BNN, dalam upaya penanggulangan masalah bahaya narkoba di Indonesia, sesuai dengan tugas dan wewenangnya BNN melaksanakan Program P4GN yaitu upaya pencegahan, pemberdayaan masyarakat, pemberantasan dan rehabilitasi. Program pencegahan narkoba ditujukan kepada masyarakat sehat yang sama sekali belum pernah mengenal narkoba agar mereka mengetahui tentang narkoba, sehingga tidak tertarik sama sekali untuk menyalahgunakannya (Towakit, 2015). Program ini selain dilakukan oleh pemerintah, juga sangat efektif apabila dibantu oleh sebuah instansi dan institusi lain termasuk lembaga-lembaga profesional terkait, lembaga swadaya masyarakat, perkumpulan, organisasi masyarakat dan lainnya.

\section{Pertanyaan Penelitian}

Pertanyaan penelitian 1: Bagaimana proses komunikasi yang dilakukan oleh Tim Program Kelurahan Bersinar dalam pencegahan penyalahgunaan narkoba kepada masyarakat di Kelurahan Tanah Seribu Binjai?

Pertanyaan penelitian 2: Bagaimana hambatan-hambatan komunikasi yang dialami oleh Tim Program Kelurahan Bersinar dalam pencegahan penyalahgunaan narkoba kepada masyarakat di Kelurahan Tanah Seribu Binjai.

\section{METODE}

Penelitian ini bersifat kualitatif dengan menggunakan paradigma post-positivisme interpretif, karena paradigma ini bersifat naturalistik, artinya peneliti mengumpulkan data yang sifatnya kualitatif dan sifatnya yang induktif mendorong adanya kreativitas dari peneliti. Peneliti memutuskan untuk menggunakan paradigma interpretif karena paradigma ini lebih sensitif serta adaptif terhadap adanya kenyataan atau kebenaran ganda yang dapat diungkapkannya sesuai dengan data yang didapatkan di lapangan.

Penelitian ini menggunakan pendekatan deskriptif, yaitu dengan menggali dan 
mengungkapkan datan dan informasi melalui wawancara dan mendeskripsikannya bentuk laporan.

Subjek penelitian ditentukan berdasarkan kriteria tertentu yang lebih spesifik. Setelah itu, ditentukanlah informan dalam penelitian ini berdasarkan kriteria tadi yaitu kriteria berdasarkan Tim Program Kelurahan Bersinar, yaitu Lurah yang menjabat pada saat program Kelurahan Bersinar Tanah Seribu dilaksanakan, Subkoordinator Pencegahan dan Pemberdayaan Masyarakat pada Badan Narkotika Nasional Kota Binjai, dan anggota Tim Kelurahan Bersinar. Kriteria kedua adalah berdasarkan masyarakat Kelurahan Tanah Seribu yang pernah mengikuti kegiatan Kelurahan Bersinar sebanyak 3 orang. Teknik pengumpulan data dilakukan pada bulan April-Juli 2021, dengan cara wawancara mendalam, observasi, studi pustaka, dan dokumentasi. Teknik analisis data menggunakan analisa data kualitatif model interaktif dari Miles dan Huberman (Sugiyono, 2017:133) yang terdiri dari reduksi data, penyajian data, penarikan kesimpulan. Menjamin keabsahan data yang diperoleh, maka peneliti mengikuti beberapa kriteria pengecekan, yaitu derajat kepercayaan (credibility), keteralihan (transferability), kebergantungan (dependability), kepastian (confirmability). Peneliti kemudian menetapkan informan yang dijadikan sebagai triangulasi data, yaitu seorang tokoh agama di Kelurahan Tanah Seribu Binjai, Kepala Badan Narkotika Nasional Kota Binjai, dan seorang wartawan media lokal Kota Binjai.

\section{HASIL DAN PEMBAHASAN}

Proses komunikasi secara berkelompok

Komunikator adalah pihak yang menjadi sumber pesan atau pihak yang menjadi inisiator awal dalam terjadinya proses komunikasi. Pihak komunikator dalam Program Kelurahan Bersinar di Tanah Seribu berasal dari beberapa pihak. Seluruh informan menyatakan bahwa yang menjadi pihak komunikator dalam program ini adalah pihak dari Badan Narkotika Nasional Kota Binjai dan Lurah Tanah Seribu. 5 informan menyatakan ada peran relawan narkoba di dalam program, dan 2 informan menyatakan ada peran Dai dari Forum Masyarakat Anti Narkoba. Orang-orang yang dipilih untuk dapat berbicara menyampaikan pesan pencegahan narkoba kepada masyarakat adalah orang-orang yang dianggap kompeten dan mampu menjelaskan materi sesuai dengan bidang yang ditekuninya.

Sesuai dengan karateristik komunikator dalam komunikasi pembangunan menurut Quebral (Cangara, 2020:327), komunikator dalam kegiatan Program Kelurahan Bersinar Tanah Seribu telah memenuhi kriteria memahami proses pembangunan, proses komunikasi dan kondisi lingkungan Kelurahan Tanah Seribu yang berlokasi di Kota Binjai. Komunikator memahami metode yang tepat dalam melakukan pendekatan kepada masyarakat. Karakteristik masyarakat Kelurahan Tanah Seribu dianggap masih erat hubungan kekerabatannya sehingga pendekatan dalam forum keagamaan sesuai usulan dari pihak Lurah dan jajarannya diputuskan sebagai pendekatan utama.

Pesan dalam komunikasi pembangunan menurut Cangara (2020:328) adalah isi komunikasi yang bisa berupa informasi, inovasi, teknologi, dan pengetahuan yang disampaikan oleh para komunikator kepada khalayak penerima.

Pesan yang disampaikan dalam komunikasi Program Kelurahan Bersinar di Tanah Seribu adalah pesan-pesan seputar pencegahan penyalahgunaan narkoba, yaitu memberikan informasi tentang narkoba menurut undang-undang yang berlaku, yang termasuk dalam golongan narkoba, indikasi penyalahgunaan narkoba, dan pencegahan penyalahgunaan narkoba yang dapat dilakukan. Pesan-pesan ini juga ada didalam media spanduk, baliho dan banner yang digunakan sebagai pendukung kegiatan.

Media adalah sarana atau saluran yang dipergunakan dalam mekanisme penyampaian 
pesan. Program Kelurahan Bersinar Tanah Seribu memfokuskan penggunaan saluran komunikasi tatap muka dan juga komunikasi melalui media luar dan dalam ruang. Saluran komunikasi yang digunakan melalui pertemuan tatap muka memanfaatkan pendekatan keagamaan, seperti forum perwiritan, pengajian dan remaja masjid. Pertemuan tatap muka lainnya adalah dengan mengumpulkan tokoh masyarakat dan pemuda yang tergabung dalam Organisasi Karang Taruna. Saluran komunikasi dengan pendekatan seperti ini dapat digolongkan dalam komunikasi sosial, masyarakat yang biasanya berkumpul dalam rangka keagamaan disisipi program pencegahan narkoba oleh para informan.

Komunikasi massa turut pula dipakai dalam program dengan mengumpulkan masyarakat banyak dalam kegiatan pencanangan. Kegiatan ini dianggap sebagai puncak kegiatan program, sekaligus menarik perhatian masyarakat secara besar-besaran karena mengundang para stakeholder pemerintahan yang terlibat dalam program.

Pertemuan tatap muka yang dilakukan diupayakan untuk menarik perhatian

pendengar. Cara-cara yang digunakan adalah (1) Menggunakan alat bantu seperti pengeras suara, laptop, dan proyektor; (2) Memuat foto dan video yang dapat menyentuh hati peserta untuk mau menjauhi penyalahgunaan narkoba, seperti gambar orang-orang yang hancur penampilan fisiknya karena narkoba, video yang menunjukkan penyalahgunaan narkoba; (3)Mengadakan kuis untuk menarik minat peserta kegiatan; (4) Membuat program pemberian bantuan peralatan, pelatihan keterampilan, kacamata gratis, pengecekan kesehatan gratis, senam bersama pada saat pencanangan untuk menarik animo masyarakat banyak. Saluran lain yang digunakan adalah dengan memajang spanduk, baliho dan banner. Spanduk dan baliho diletakkan di lokasi-lokasi strategis yang kemungkinan besar dilalui orang banyak, terutama warga Tanah Seribu sedangkan banner diletakkan di kantor Kelurahan Tanah Seribu.

Komunikan adalah pihak yang menerima pesan. Komunikan dalam program Kelurahan Bersinar ini adalah masyarakat Kelurahan Tanah Seribu. Khalayak atau komunikan dalam komunikasi pembangunan adalah mereka yang memerlukan bantuan penyadaran, pengetahuan, keterampilan dan fasilitas yang bisa digunakan untuk meningkatkan taraf hidupnya menjadi lebih sejahtera (Cangara, 2020:330). Sasaran dalam program ini telah sesuai dengan konsep komunikasi pembangunan. Masyarakat yang dipilih untuk mendapatkan pelatihan keterampilan dan pemberian bantuan peralatan adalah pemuda yang tinggal di Kelurahan Tanah Seribu dengan harapan dapat menambah kemampuan para pemuda dalam budidaya tanaman masyarakat sesuai dengan profesi masyarakat Kelurahan Tanah Seribu yang merupakan petani dan pedagang. Keterlibatan komunikator dan Komunikan dalam Program Kelurahan Bersinar Tanah Seribu telah sesuai dengan apa yang dinyatakan Towakit (2014) dalam penelitiannya. Towakit menyatakan bahwa program P4GN perlu dilaksanakan secara terpadu, melibatkan berbagai unsur pemerintah dan masyarakat. Komunikator memberikan penyadaran kepada komunikan untuk dapat lebih mengenal pencegahan penyalahgunaan narkoba, dengan harapan masyarakat dapat tersadarkan dan dapat memberikan informasi tersebut kepada masyarakat lainnya.

Efek adalah tanggapan, persepsi, dan opini dari komunikan sebagai akibat dari adanya proses komunikasi yang telah terjadi. Efek dapat berupa perbedaan antara apa yang dipikirkan, dirasakan dan dilakukan oleh penerima sebelum dan sesudah menerima pesan (Stuart dalam Cangara, 2020:331). Ada efek positif yang dirasakan terkait adanya program Kelurahan Bersinar di Tanah Seribu. Efek positif itu adalah seputar sikap setuju program dilaksanakan di lingkungannya karena informan menganggap bahwa tujuan program adalah demi kebaikan bersama. Informan menyatakan tidak ada penolakan dari kalangan masyarakat yang mereka ketahui terkait program ini. 
Proses Komunikasi Melalui Media Luar dan Dalam Ruang

Komunikasi melalui media luar dan dalam ruang dalam Program Kelurahan Bersinar digunakan sebagai pendukung dalam kegiatan, artinya media ini dianggap sebagai media yang ampuh memberikan informasi kepada masyarakat banyak dengan biaya yang relatif murah. Komunikasi melalui media luar ruang yang digunakan berupa spanduk dan baliho, sedangkan komunikasi melalui media dalam ruang melalui banner. Spanduk yang digunakan dalam program ini merupakan bantuan dari pihak kecamatan. Pihak kecamatan memberikan dukungan dalam program dengan pencetakan spanduk. Baliho adalah bentuk partisipasi warga yang mendapatkan pelatihan sablon dari kegiatan yang diselenggarakan oleh Lembaga Pengabdian Masyarakat Universitas Sumatera Utara, dan $x$-banner dicetak oleh Badan Narkotika Nasional Kota Binjai. Pihak Kelurahan pada komunikasi jenis ini tidak terlalu berperan, dikarenakan anggaran Kelurahan yang tidak memadai untuk memproduksi media-media sejenis.

Pesan yang disampaikan dalam spanduk adalah seputar ajakan untuk bersama-sama melakukan penyalahgunaan narkoba di Kelurahan Tanah Seribu Binjai, dan ajakan untuk mensukseskan Program Kelurahan Bersinar di Kelurahan Tanah Seribu.

Media yang digunakan adalah komunikasi luar ruang yaitu spanduk dan baliho, dan media dalam ruang yaitu $x$-banner. Pihak komunikator menentukan media ini karena sifat-sifat yang dimilikinya, yaitu biaya produksi murah, dipasang di lokasi strategis untuk memberikan informasi kepada siapa saja yang melintas, artinya informasi bisa diterima oleh siapa saja yang bisa membaca pesan sehingga informasi ini dapat diketahui oleh masyarakat luas baik penyalahguna maupun yang bukan penyalahguna.

Komunikan yang menjadi sasaran penggunaan media ini sama dengan komunikan yang menjadi sasaran dalam komunikasi tatap muka secara berkelompok, yaitu masyarakat Kelurahan Tanah Seribu. Tidak menutup kemungkinan bahwa orang yang membaca pesannya berasal dari luar Kelurahan Tanah Seribu.

Informan tim program menyatakan bahwa efek atau tujuan yang ingin dicapai dengan penggunaan media komunikasi luar dan dalam ruang adalah sebatas memberikan informasi kepada masyarakat, namun tidak menutup kemungkinan adanya tindakan baru yang ingin dicapai setelah membaca pesan.

Hambatan Komunikasi

Usaha-usaha untuk berkomunikasi dengan baik bisa terganggu oleh karena adanya hambatan yang mengganggu proses komunikasi, terutama jika komunikan terdiri atas banyak orang.

Hambatan teknis adalah hambatan yang terjadi karena kurangnya sarana dan prasarana yang diperlukan dalam proses komunikasi, penguasaan teknis dan metode komunikasi yang tidak sesuai dan kondisi fisik yang tidak memungkinkan terjadinya komunikasi. Hambatan teknis yang terjadi dalam proses komunikasi Kelurahan Bersinar adalah berupa ketidakhadiran peserta kegiatan karena jadwal kegiatan yang bentrok dengan jadwal pribadi, namun hal ini dapat diatasi dengan cara mencari penggantinya.

Hambatan teknis dalam bermedia, baik luar dan dalam ruang berupa tidak terlihatnya spanduk/baliho/banner yang dipajang di perempatan oleh sebagian masyarakat karena tidak melewati jalur tersebut sehari-hari. Hambatan teknis yang perlu digaris bawahi dalam program Kelurahan Bersinar di Tanah Seribu adalah surat edaran untuk mengusulkan nama kelurahan/desa yang hendak dicanangkan dalam program tidak dibarengi dengan petunjuk teknis penyelenggaraan.

Hambatan semantik terjadi karena kesalahan dalam menafsirkan ataupun 
menyampaikan pesan dalam proses komunikasi yang dilakukan. Hambatan ini berkaitan dengan penggunaan bahasa atau lisan yang mungkin salah diartikan atau direspon oleh komunikan. Program ini dinamakan 'Kelurahan Bersinar' dimana memberikan salah penafsiran di masyarakat bagi yang tidak terlalu memperhatiakan apa kepanjangan dari singkatan 'Bersinar'.

Hambatan perilaku dominan menjadi masalah terbesar dalam mengubah gaya hidup atau dalam hal mengajarkan pola hidup tertentu kepada masyarakat. Hambatan perilaku dalam komunikasi Tim Kelurahan Bersinar timbul karena adanya kekecewaan kepada petugas hukum yang membidangi pemberantasan narkoba di Indonesia pada umumnya dominan terjadi di masyarakat. Pemberitaan-pemberitaan terkait lolosnya narkoba ribuan ton melalui berbagai jalur transportasi, adanya permainan antara petugas penegak hukum dengan bandar narkoba, ataupun berdasarkan pengalaman pribadi dimana pengedar dapat bebas tak lama setelah dilakukan penangkapan. Kejadian-kejadian seperti ini menjadikan tingkat rasa percaya kepada masyarakat semakin menurun pada bidang pemberantasan narkoba, alhasil prasangka-prasangka negatif kepada petugas selalu ada dalam program Kelurahan Bersinar di Tanah Seribu dan menjadi faktor penghambat utama.

\section{PENUTUP}

Komunikasi yang dilakukan dalam Program Kelurahan Bersinar Tanah Seribu difokuskan pada tiga bentuk yaitu dengan komunikasi tatap muka secara berkelompok, komunikasi melalui media luar ruang dan komunikasi dalam ruang. Komunikasi tatap muka secara berkelompok menjadi titik berat program karena bersifat langsung dan lebih dari satu orang dalam sekali penyampaian. Pendekatan yang ditekankan adalah melalui kegiatan agama dan kelompok organisasi yang bertujuan menjangkau masyarakat yang berasal dari berbagai tingkatan umur, pendidikan dan ekonomi. Komunikasi melalui media luar dan dalam ruang digunakan untuk mendukung kegiatan dalam menjangkau masyarakat dalam jumlah yang lebih banyak.

Hambatan-hambatan komunikasi yang dihadapi dalam Program Kelurahan Bersinar meliputi teknis, semantik dan perilaku. Hambatan perilaku merupakan hambatan terbesar dalam proses komunikasi Kelurahan Bersinar karena adanya stigma di masyarakat.

Program-program yang berkaitan dengan kegiatan komunikasi pembangunan yang dilakukan kepada masyarakat agar kedepannya dapat dilakukan secara inovatif, intensif dan berkesinambungan, khususnya dalam pencegahan penyalahgunaan narkoba.

\section{DAFTAR PUSTAKA}

Cangara, Hafied. (2020). Komunikasi Pembangunan. Depok: PT Rajagrafindo Persada.

Persada.

(2014). Pengantar Ilmu Komunikasi. Jakarta: PT Rajagrafindo

Nasution, Belli; Rasyid, Anuar. (2019). Buku Ajar Komunikasi Sosial dan Pembangunan. Pekanbaru: Taman Karya.

Novita, Hesti; Hairunnisa; Dristina, Kadek D. (2020). Efektivitas Penggunaan Media Luar Ruang Sebagai Media Komunikasi Satuan Lalu Lintas Polresta Samarinda Dalam Menyadarkan Masyarakat Saat Berkendara. Jurnal Ilmu Komunikasi. 8 (2), 296-305.

Silviani, Irene. (2020). Komunikasi Organisasi. Surabaya: PT Scopindo Media Pustaka. 
Sugiyono. (2017). Metode Penelitian Kombinasi. Jakarta: Alfabeta.

Supratman, Dindin. (2018). Prevalensi Usia Pemuda Dan Ketahanan Nasional (Narkotika Dan Ancaman Lost Generation). Jurnal Litbang Sukowati. 1 (2), 118127.

Towakit, Jethan. (2014). Pedoman Pelaksanaan P4GN Melalui Peran Serta Kepala Desa/Lurah di Tingkat Desa/Kelurahan. Jurnal Tadbir. 2 (2). 155-160. 